Archives of Agriculture and Environmental Science

\title{
Cost-benefit analysis and resource use efficiency of rice production system in different agriculture landscapes in Chitwan district, Nepal
}

\author{
Roshan Dhakal ${ }^{1}$, Sandesh Bhandari ${ }^{1 *}$ (D) , Binod Joshi ${ }^{1}$, Amrit Aryal ${ }^{1}$, Rishi Ram Kattel ${ }^{2}$ and Shiva \\ Chandra Dhakal ${ }^{2}$ \\ ${ }^{1}$ Faculty of Agriculture, Agriculture and Forestry University, Rampur, Chitwan, NEPAL \\ ${ }^{2}$ Department of Agricultural Economics and Agribusiness Management, Faculty of Agriculture, Agriculture and Forestry University, \\ Rampur, Chitwan, NEPAL \\ *Corresponding author's E-mail: bhandarisandesh2000@gmail.com
}

\section{ARTICLE HISTORY}

Received: 03 October 2019

Revised received: 28 October 2019

Accepted: 16 November 2019

\section{Keywords}

Agriculture landscape

Benefit-Cost ratio

Gross profit

Resource use efficiency

Rice production

\section{ABSTRACT}

The study was conducted to determine the cost-benefit analysis and resource use efficiency of the rice production system in different agriculture landscapes in the Chitwan district in 2018. The sample size of 102 rice-growing farmers out of 600 farmers, having an area of farm size greater than 0.5 hectares, was determined using Raosoft Inc. Software. A simple random sampling technique was used to collect 102 rice-growing household information in four municipalities ( 2 in plain and 2 in hilly area) using a semi-structured questionnaire. Data were analyzed using descriptive and statistical tools including Cobb-Douglas production function. Results showed that the use of inputs like seeds, chemical fertilizer and machinery like tractor were found significantly higher in the plain area whereas the use of inputs like labor, farmyard manure (FYM) and bullocks was found in higher in the hilly area. The costs of fertilizer, machinery, pesticide, and transportation were found higher in the plain area whereas the costs of seed, FYM, labor and bullocks were significantly higher in the hilly area. Production of rice per household was 1.87 ton whereas productivity was 5.2 ton/ha, gross profit was NRs. 41435 and benefit-cost ratio was 1.59 in the plain area which was found significantly higher than the hilly area. The return to scale was found to be 0.48 which revealed that inputs used in rice production were ineffectively utilized in which organic fertilizer and labor resource were overused and seed, fertilizer, machinery and bullocks, pesticides and transportation were underused resources. The optimal allocation of these resources will increase the profitability of rice farming.

(C)2019 Agriculture and Environmental Science Academy

Citation of this article: Dhakal, R., Bhandari, S., Joshi, B., Aryal, A., Kattel, R.R. and Dhakal, S.C. (2019). Cost-benefit analysis and resource use efficiency of rice production system in different agriculture landscapes in Chitwan district, Nepal. Archives of Agriculture and Environmental Science, 4(4): 442-448, https://dx.doi.org/10.26832/24566632.2019.0404011

\section{INTRODUCTION}

Nepal is an agricultural country where cereal crops are mostly grown for subsistence as well as for commercial purposes. According to CBS (2017), agriculture alone contributes around $27.04 \%$ of total GDP. Agriculture is the bulwark of the Nepalese economy where around $65 \%$ of the population is engaged in agriculture (CBS, 2017). Rice (Oryza sativa) is the most important food crop of Nepali in terms of both area and production. Rice plays a foremost role in the food security of our coun- try and is regarded as the prime cereal crop of a nation. Rice contributes around $18 \%$ to Agriculture Gross Domestic Product (AGDP) of the country (CDD, 2015). The cultivation area and production of rice in Nepal are about 15523 thousand hectares and 5230 thousand ton respectively whereas the productivity is about $3.4 \mathrm{t} \mathrm{ha-}{ }^{1}$ (MOF, 2017). Nearly, $50 \%$ of daily calorie requirement is fulfilled by the rice crops alone. In Asia alone, around 2 billion people derive around $80 \%$ of their energy requirement, from rice that contains $80 \%$ carbohydrate, $7-8 \%$ proteins, 3\% fat and 3\% fiber (Juliano, 1985). The total dietary 
energy supplied by the cereal crops in the context of Nepal is around 56\%, among which rice alone share around 30\% (MOAD, 2016).

In the context of Nepal average landholding size is comparatively less around 0.68 hectare which is one of the major reasons for impeding the production potential of the nation (NFS, 2010). Due to the decrease in yield and production of cereal crops, farmers have shifted from cereal cultivation to cash crops which ultimately decrease cereal crop production (Deshar, 2013). The major factor affecting the technical efficiency of rice production includes seed, fertilizer labor as well as irrigation (Hasnian and Hossain, 2015). For increasing the production of rice, the use of improved farm mechanization and input is the best way (Nargis and Lee, 2013).

Chitwan district is one of the dominant rice-growing districts in Nepal where rice is grown during spring and monsoon season. Although, it is regarded as the rice hub of the nation the yield in rice production is still comparatively lower as compared to another bordering district with similar geographical characteristics. The major insecurity in rice production is due to lack of quality seed, proper irrigation system, the inadequate linkage between research, extension, and teaching as well as the incapability to use modern technology. From cultivation to harvesting stage, the farmers of Nepal as well as of Chitwan are still using the same conventional tools and equipment which is a major cause for the yield reduction in Chitwan. At the present time also, the farmers of the hilly area are still dependent on the sickles for the harvesting procedure of rice which ultimately leads to a decrease in the efficiency of farmers (Shrestha, 2012). Farmers do not have adequate knowledge of resource optimization and as a result, they are not able to use the resources at their optimum level which is becoming the major cause for the yield reduction in Chitwan. The maximum production of rice is

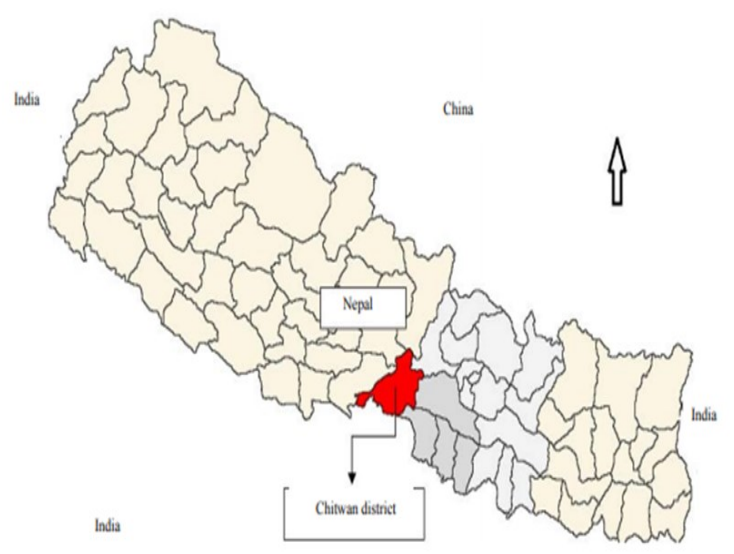

Figure 1. Map of Nepal with its border countries; India on three sides and china at north sidealong with red region showing study area which is at the southern part of country bordered with India (Source: Osti et al., 2017). achievable only through improvement in crop productivity which is obtained through the utilization of efficient resources. This optimum utilization of resources ultimately leads to an increase in the profit margin. For obtaining maximum production from any agricultural commodity, resources must be available and available resources must be used efficiently and for this purpose, one must have knowledge about whose quantity rate should be increased or decreased (Alimi, 2000).

For any agricultural production system to be productive and efficient, the input used is the most important parameter. There is no study carried out to date to study the resource use efficiency of input for better production and productivity of rice in Nepal. Such a backdrop, this study is mainly focused to assess the profitability, level of resource uses and efficiency in rice production.

\section{MATERIALS AND METHODS}

\section{Study area}

Amongst the various cereals producing districts of Nepal, Chitwan district is one of the highest rice producing districts with great potential in cereal production and regarded as the food basket of the country (MOAD, 2016). So this district was selected for the study purpose. Chitwan district is located at Province no 3 of Nepal which lies between 27E21' to 27E52' North latitude and 83E54' to 84E48' East longitude with a total land area of 218000 ha, located at an altitude of 141-1943 m (Figure 1). The annual rainfall: $1950.7 \mathrm{Mm}$, mean temperature: $32.2-18 \mathrm{EC}$ and average relative humidity: $83 \% \mathrm{~m}$ (Osti et al., 2016). Within the district, four municipalities consisting of two hilly area (Rapti and Icchakamana) and two terai area (Khaireni and Bharatpur) were selected for the study purpose (Figure 1, Table 1).

\section{Sampling design}

The numbers of households producing rice commercially having the farm size greater than 10 ropani were purposively selected for the study which was found to be 600 . The objective was to find the real rice farmers so to get the valid data covering the whole rice farmers. Raosoft Inc. software, which was considered as a scientific and standard technique for the determination of sample size, was used to determine the required sample size (Raosoft, 2014). Using the software, keeping 95\% level of confidence and margin of error $10 \%$, it recommended the sample size to be 91.The simple random technique was used to select sample to minimize the biasness as possible as the it is considered as the best way which provides an equal chance for selection of the elements from the sampling frame (Scheaffer, 1979). The sample size of 102 was taken for the study (Table 1 ).

Table 1. Sampling frame used in the household survey, 2018.

\begin{tabular}{lllll}
\hline S.N. & Area of survey & Municipality & Population size (N) & Sample size(n) \\
\hline 1. & Plain area & Khairani Municipality & 177 & 30 \\
2. & Plain area & Bharatpur Metropolitan City & 176 & 30 \\
3. & Hilly area & Rapti Municipality & 172 & 29 \\
4. & Hilly area & Ichhakamana Rural Municipality & 75 & 13 \\
Total & & & 600 & 102 \\
\hline
\end{tabular}


Data collection and analysis

At first of all, pre-testing of questionnaire was done in Khaireni Municipality with 10 respondents, which is common in pre-test of questionnaire (Perneger et al., 2015). Along with the improvements in the pre tested questionnaire, it was finally administered in December, 2018. Semi-structured interview schedule was used for the primary collection of data which were further confirmed by the data collected through Focus group discussion (FGD) and key informant interview (KII). The primary data consist of data related to farm input like seed, land size, organic manure, chemical fertilizer, labor, irrigation and output of rice along with their byproduct; their quantity and associated price. The secondary data were acquired through DADO annual report, articles, newspaper, books and Department of Agriculture.

The acquired data were systematically arranged and coded and entered in Ms-Excel and SPSS software for the analysis purpose. The results were derived by using descriptive statistics, mean comparison and Cobb-Douglas production function.

\section{Cost and return analysis}

To calculate the total variable cost, inputs like human labor, tractor labor, seed, inorganic or chemical fertilizers, irrigation, pesticides and organic manures including transportation costwere considered and they were valued at current market prices to calculate cost of production.

Total variable cost $=\mathrm{C}_{\text {labor }}+\mathrm{C}_{\text {tractor }}+\mathrm{C}_{\text {seed }}+\mathrm{C}_{\text {fert }}+\mathrm{C}_{\text {irri }}+\mathrm{C}_{\text {pesti }}+$ $\mathrm{C}_{\text {manure }}+\mathrm{C}_{\text {trans }}$ Where, $\mathrm{C}_{\text {labor }}=$ Cost on human labor used (NRs./ ha), $C_{\text {tractor }}=$ Cost on tractor labor used (NRs./ha), $C_{\text {seed }}=$ Cost on seed (NRs./ha), $\mathrm{C}_{\text {fert }}=$ Cost on inorganic chemical fertilizers (NRs./ha), $\mathrm{C}_{\text {irri }}=$ Cost on irrigation (NRs./ha) $\mathrm{C}_{\text {pesti }}=$ Cost on pesticides (NRs./ha), $\mathrm{C}_{\text {manure }}=$ Cost on organic manures (NRs./ ha) and $\mathrm{C}_{\text {trans }}=$ Cost of transportation (NRs./ha)

Similarly, gross return was calculated as:

Gross Return $=($ Price of rice seed $\times$ Total amount of rice seed $)+$ (Price of Rice by product (Bhus) $\times$ Total amount of Rice by product (Bhus)

Similarly, undiscounted benefit cost ratio was estimated by following formula, as used by Dhakal et al. (2015).

Benefit Cost Ratio $(B C R)=$ Gross return $/$ total variable cost Furthermore, Gross margin was calculated using following formula;

Gross Margin (NRs./ha) = Gross return (NRs./ha) - Total variable cost (NRs./ha) (Olukosi et. al., 2016)

Resource use analysis using Cobb-Douglas production function To determine the contribution of different inputs as well as for the estimation of the efficiency of variable production input in rice production system, Cobb-Douglas production function was used as described by Gujarati (2009). The general form of
Cobb-Douglas production function was used to determine resource productivity, efficiency and return to scale is as follow:

$\mathrm{Y}=\mathrm{a} \mathrm{X}_{1}^{\mathrm{b} 1} \mathrm{X}_{2}^{\mathrm{b} 2} \mathrm{X}_{3}^{\mathrm{b} 4} \mathrm{X}_{5}^{\mathrm{b} 5} \mathrm{X}_{6}{ }^{\mathrm{b} 6} \mathrm{X}_{7}{ }^{\mathrm{b} 7} \mathrm{e}^{\mathrm{u}}$

Where, $Y=$ Gross return (NRs./ha ), $\mathrm{X}_{1=}$ Cost on seed (NRs./ha ), $\mathrm{X}_{2}=$ Cost on Fertilizer (NRs./ha ), $\mathrm{X}_{3}$ Cost on manure (NRs./ha), $\mathrm{X}_{4}=$ Cost on machinery and bullock (NRs./ha ), $\mathrm{X}_{5}=$ Cost on pesticide (NRs./ha ), $X_{6}=$ cost on labor (NRs./ha ), $X_{7=}$ cost on transportation, $\mathrm{e}=$ base of natural logarithm, $\mathrm{u}=$ random disturbance term, a=constant and b1,b2...b7 are coefficient of respective variable.

The resource use efficiency ratio ( $r$ ), absolute value of percentage change in MVP (D) and return to scale (RTS) was estimated by using the following formula, as calculated by Sapkota et al. (2018).

\section{$r=M V P / M F C$}

Where,

MFC=Marginal Factor Cost and MVP= Marginal Value Product of variable input

The marginal value product is as follows: $M V P=b_{i} \times A P P_{i}$

Where: $b_{i}=$ Elasticities of various input and APP $=$ Geometric mean of output $Y /$ Geometric mean of output $X_{i}$

If $r=1,>1$ or $<1$, it indicates the efficient, underused or overused of resources respectively.

Similarly, the absolute value of percentage change in MVP of each resource was estimated as $D=(1-M F C / M V P) \times 100$ Where, $D=$ Absolute value of percentage change in MVP of each resource Return to scale analysis (RTS) The return to scale was calculated as follow: $\mathrm{RTS}=\sum$ bi If $\mathrm{RTS}=1,>1$ or $<1$, it indicates the constant, increasing and decreasing rate of scale respectively.

\section{RESULTS AND DISCUSSION}

Input used in rice cropping system in different geographical region

The major inputs used during the rice production includes Seed, Labour, FYM, Chemical fertilizers, Tractors/Bullocks (Table 2). The average amount of Seed, Labour, FYM, Chemical fertilizers, Tractor/thresher and Bullocks were $52.55 \mathrm{Kg}, 75.99$ man-days, $4411.60 \mathrm{Kg}, 117.59 \mathrm{Kg}, 16$ hour and 10.48 days, respectively. These seeds, labour, FYM and chemical fertilizer have significant effect in the rice production. According to Ogundele and Okoruwa (2006), fertilizer is one of the most critical inputs in rice production. The amount of seed required was significantly higher in plain area $(52.19 \mathrm{Kg} / \mathrm{ha})$ than hilly area $(43.19 \mathrm{Kg} / \mathrm{ha})$ 
Table 2. Input used in rice cropping system in the studied sites.

\begin{tabular}{|c|c|c|c|c|c|c|}
\hline \multirow{2}{*}{ Variable } & \multirow{2}{*}{ Overall } & \multirow[t]{2}{*}{ Plain area } & \multirow{2}{*}{ Hilly area } & \multirow{2}{*}{ Mean difference } & \multicolumn{2}{|l|}{$\mathrm{T}$ test } \\
\hline & & & & & T value & P value \\
\hline Seed (kg) & $\begin{array}{l}52.25 \\
(29.88)\end{array}$ & $\begin{array}{l}59.19 \\
(22.07)\end{array}$ & $\begin{array}{l}43.19 \\
-36.01\end{array}$ & $15.99^{* * *}$ & 2.821 & 0.006 \\
\hline Labour (man- days) & $\begin{array}{l}75.99 \\
(48.12)\end{array}$ & $\begin{array}{l}57.83 \\
(19.94)\end{array}$ & $\begin{array}{l}101.94 \\
(62.9)\end{array}$ & $-44.10^{* * *}$ & -5.085 & 0.000 \\
\hline FYM (kg) & $\begin{array}{l}4411.6 \\
(4400.6)\end{array}$ & $\begin{array}{l}3584.54 \\
(3422.2)\end{array}$ & $\begin{array}{l}5535.55 \\
(4755)\end{array}$ & $-1951.01^{* *}$ & -2.104 & 0.038 \\
\hline Chemical fertilizer (kg) & $\begin{array}{l}117.59 \\
(98.72)\end{array}$ & $\begin{array}{l}162.03 \\
(76.45)\end{array}$ & $\begin{array}{l}70.82 \\
(62.42)\end{array}$ & $91.20^{* * *}$ & 5.613 & 0.00 \\
\hline Urea (kg) & $\begin{array}{l}61.49 \\
(57.74)\end{array}$ & $\begin{array}{l}71.99 \\
(51)\end{array}$ & $\begin{array}{l}50.44 \\
(42.63)\end{array}$ & $21.54^{* *}$ & 2.045 & 0.043 \\
\hline DAP (kg) & $\begin{array}{l}45.88 \\
(36.87)\end{array}$ & $\begin{array}{l}73 \\
(40.09)\end{array}$ & $\begin{array}{l}17.26 \\
(10.36)\end{array}$ & $55.81^{* * *}$ & 7.500 & 0.00 \\
\hline MOP (kg) & $\begin{array}{l}10.21 \\
(8.23) \\
16\end{array}$ & $\begin{array}{l}16.96 \\
(18.17 \\
16\end{array}$ & $\begin{array}{l}3.11 \\
(2.11)\end{array}$ & $13.84^{* * *}$ & 4.854 & 0.000 \\
\hline Tractor/ Thresher (hour) & $(5.55)$ & (5.55) & 0 & 16.00 & ---- & ---- \\
\hline Bullocks (days) & $\begin{array}{l}16.99 \\
(10.48)\end{array}$ & 0 & $\begin{array}{l}16.99 \\
(10.48)\end{array}$ & -16.99 & ----- & ---- \\
\hline
\end{tabular}

Notes: ${ }^{* *},{ }^{* * *}$ indicate significant at $5 \%$ and $1 \%$ levels, respectively. Figures in parentheses indicate the standard deviation of the means.

Table 3. Comparative cost of rice cropping system (NRs. per hectare) in the major two studied sites.

\begin{tabular}{|c|c|c|c|c|c|c|c|c|c|}
\hline Costs (NRs./ha) & Overall & Plain area & Hilly area & $\begin{array}{c}\text { Mean } \\
\text { difference }\end{array}$ & T value & P value & $\begin{array}{l}\text { Overall } \\
\text { share } \\
(\%)\end{array}$ & $\begin{array}{l}\text { Hilly } \\
\text { share } \\
(\%)\end{array}$ & $\begin{array}{c}\text { Plain } \\
\text { share } \\
(\%)\end{array}$ \\
\hline Seed cost & $\begin{array}{l}5165.97 \\
(3993.2)\end{array}$ & $\begin{array}{c}4019.41 \\
(3431.06)\end{array}$ & $\begin{array}{c}6803.91 \\
(4203.36)\end{array}$ & $-2784.5^{* * *}$ & -3.674 & 0.00 & 6.88 & 9.93 & 4.94 \\
\hline $\begin{array}{l}\text { Chemical } \\
\text { fertilizer cost }\end{array}$ & $\begin{array}{c}3907.7 \\
(3494.54)\end{array}$ & $\begin{array}{l}5746.03 \\
(2711.2)\end{array}$ & $\begin{array}{c}1972.75 \\
(1181.16)\end{array}$ & $3773.2^{* * *}$ & 6.91 & 0.00 & 5.2 & 2.88 & 7.07 \\
\hline FYM cost & $\begin{array}{c}8823.21 \\
(7953.13)\end{array}$ & $\begin{array}{c}7169.09 \\
(6222.49)\end{array}$ & $\begin{array}{l}11071.11 \\
(9509.92)\end{array}$ & $-3902^{* *}$ & -2.104 & 0.038 & 11.74 & 16.15 & 8.82 \\
\hline $\begin{array}{l}\text { Tractor/ } \\
\text { Thresher cost }\end{array}$ & $\begin{array}{l}28918.88 \\
(9997.48)\end{array}$ & $\begin{array}{l}28918.88 \\
(9997.48)\end{array}$ & 0 & 28918.88 & - & - & 38.49 & 0 & 35.57 \\
\hline Bullocks cost & $\begin{array}{l}16990.85 \\
(10484.9)\end{array}$ & 0 & $\begin{array}{c}16990.85 \\
(10484.92)\end{array}$ & -16990.9 & - & - & 22.61 & 24.79 & 0 \\
\hline Labour cost & $\begin{array}{l}37999.81 \\
(24062.3)\end{array}$ & $\begin{array}{l}28918.88 \\
(9997.48)\end{array}$ & $\begin{array}{c}50972.56 \\
(31454.77)\end{array}$ & $-22054^{* * *}$ & -5.085 & 0.00 & 50.57 & 74.37 & 35.57 \\
\hline Pesticide cost & $\begin{array}{c}4913.39 \\
(3844.65)\end{array}$ & $\begin{array}{c}5987.79 \\
(5564.99)\end{array}$ & $\begin{array}{c}2936.48 \\
(1939.91)\end{array}$ & $3051.31^{* *}$ & 2.155 & 0.035 & 6.54 & 4.28 & 7.36 \\
\hline $\begin{array}{l}\text { Transportation } \\
\text { cost }\end{array}$ & $\begin{array}{c}2653.37 \\
(1405.58)\end{array}$ & $\begin{array}{c}3121.06 \\
(1465.87)\end{array}$ & $\begin{array}{c}1996.37 \\
(1010.93)\end{array}$ & $1124.7^{* * *}$ & 4.295 & 0.00 & 3.53 & 2.91 & 3.84 \\
\hline $\begin{array}{l}\text { Total cost of } \\
\text { Production }\end{array}$ & $\begin{array}{l}75139.84 \\
(45471.2)\end{array}$ & $\begin{array}{c}81302.21 \\
(27576.36)\end{array}$ & $\begin{array}{c}68537.3 \\
(58494.91)\end{array}$ & 12764.91 & 1.519 & 0.131 & 100 & 100 & 100 \\
\hline
\end{tabular}

Notes: ${ }^{* *},{ }^{* *}$ indicate significant at $5 \%$ and $1 \%$ levels, respectively. Figures in parentheses indicate the standard deviation of the means.

Table 4. Yield and profitability of rice crop production in the two studied sites.

\begin{tabular}{|c|c|c|c|c|c|c|}
\hline Variables & Overall & Plain area & Hilly area & $\begin{array}{c}\text { Mean } \\
\text { difference }\end{array}$ & $\begin{array}{c}\mathrm{T} \\
\text { value }\end{array}$ & Pvalue \\
\hline $\begin{array}{l}\text { Production in } \\
\text { household (kg) }\end{array}$ & $\begin{array}{c}1966.73 \\
(1853.22)\end{array}$ & $\begin{array}{c}2757.88 \\
(2054.32)\end{array}$ & $\begin{array}{c}881.19 \\
(359.97)\end{array}$ & $1876.7^{* * *}$ & 5.81 & 0.000 \\
\hline Yield (kg/ha) & $\begin{array}{c}4422.29 \\
(2342.63)\end{array}$ & $5201.78(2443.11)$ & $3327.28(1684.89)$ & $1874.5^{* * *}$ & 4.3 & 0.000 \\
\hline Gross return (NRs./ha) & $109330.9(51273.16)$ & $\begin{array}{c}122737.63 \\
(5034.82)\end{array}$ & $\begin{array}{l}90176.33 \\
(46796.6)\end{array}$ & $32870.42^{* * *}$ & 3.31 & 0.000 \\
\hline Gross profit (NRs./ha) & $23876.88(22658.06)$ & 41435.4 (36120.9) & $-1206.73(1036.1)$ & $42552.51^{* * *}$ & 4.33 & 0.000 \\
\hline $\mathrm{B}: \mathrm{C}$ ratio & $1.43(0.72)$ & $1.5993(0.67)$ & $1.1893(0.74)$ & $0.41^{* * *}$ & 2.89 & 0.010 \\
\hline
\end{tabular}

Notes: ${ }^{* *},{ }^{* * *}$ indicate significant at $5 \%$ and $1 \%$ levels, respectively. Figures in parentheses indicate the standard deviation of the means. 
at $1 \%$ level of significance. The plain area have more leveled surface which have more surface area and required high amount of seeds. The labour used for rice cropping system was significantly higher in hilly area (101.94 man-days/ ha) than plain area (57.83 man-days/ha) at $1 \%$ level of significance. The FYM used for rice cropping was significantly higher in hilly area $(5535 \mathrm{Kg} /$ ha) than plain area $(3584 \mathrm{Kg} / \mathrm{ha})$ at $5 \%$ level of significance. The use of chemical fertilizer was significantly higher in plain area $(162.03 \mathrm{Kg})$ than hilly area $(70.82 \mathrm{Kg})$ at $1 \%$ level of significance. For the land preparation, tractor/thresher is used in plain area whereas bullocks is used in hilly area.

\section{Rice production cost}

The total cost of production of rice includes cost of inputs (seeds, fertilizers, pesticides), cost of labour/equipment's during land preparation, and, cost of harvesting and transportation. The total cost of production was higher in plain area (NRs. 81302 per ha) than the hilly area (NRs. 68537/ha). This findings was supported by the findings of (Adhikari, 2011) who reported the minimum, average and maximum cost of organic rice production in Phoolbari, Chitwan were NRs. 19485, 32249 and 74005/ha, respectively. The higher cost of production in plain area than hilly region is mainly due to the more requirement of pesticides in plain area. Due to the high temperature and humidity in plain area, there is high incidence of insect pests and disease in plain area. The cost of pesticides in plain area and hilly area were NRs. 5987/ha and NRs.2936/ha, respectively. Almost, all farmer's use the chemical fertilizers like Urea (Nitrogen source), DAP (Nitrogen and Phosphorus source) and $\mathrm{KCl}$ (Potassium Source) in plain area and, however, there was exception in the hilly area and amount was also in low quantity in the used cases. The cost of chemical fertilizer was significantly higher in plain area (NRs. 5746/ha) than hilly area (NRs.1972/ha). And, the cost of FYM was higher in hilly area (NRs.11071/ha) than plain area (NRs.7169/ha). Farmer's of hilly area generally prefers FYM due to locally available in farms and less accessibility of chemical fertilizers in time. The high user of chemical fertilizer in plain area was due to easy availability. The cost of seed was also significantly higher in hill area (NRs.6803/ha) than plain area (NRs.4019/ha). During the land preparation, there was a uses of Bullock in hilly area whereas, tractor in the plain area along with human labour in both cases (Table 3).

Yield and profitability of rice production

The total average production in the study household was $1966.73 \mathrm{Kg}$. The average rice yield in household was 4422.29 $\mathrm{kg} / \mathrm{ha}$ and it was significantly higher in plain area $(5201.78 \mathrm{~kg} /$ ha) than hilly area $(3327.28 \mathrm{~kg} / \mathrm{ha})$. Due to the more fertile soil and irrigation facilities, there is higher yield in the plain area. The average gross return from rice production is NRs.109330/ ha which was significantly higher in plain area (NRs. 122737/ha) than hilly area (NRs.9017/ha). The higher return of plain area was due to the higher production in plain area (Table 4).

The average gross profit was NRs. 2387.88/ha which was significantly higher in Plain area (NRs.41435.4/ha) than hilly area (NRs. 1206.73/ha). The negative sign in hilly area indicates the loss which was due to the higher cost of production in hilly area. And, the Benefit Cost Ratio (BCR) was also significantly higher in plain area (1.60) than hilly area (1.19). This indicates, spending one rupee provides the benefit of NRs.0.6 in plain area and NRs.0.19 in plain area respectively. Thus, it was more profitable in the plain area and also the plain area is considered as the "Granary of Nepal". The low value of BCR in hilly area than plain area is due to the high cost of production in hilly area in the case of labour and FYM. The average BCR (1.43) of Chitwan contradicts with the mean BCR (1.19) of Kapilvastu (Sapkota and Sapkota, 2019).

Table 5. Estimation of elasticity, MVP and efficiency ratios using Cobb Douglas Production function of rice cropping system in Chitwan.

\begin{tabular}{|c|c|c|c|c|c|c|c|}
\hline $\begin{array}{l}\text { Variables } \\
\text { Cost (NRs./ha) }\end{array}$ & Coefficients & $\begin{array}{l}\text { Standard } \\
\text { error }\end{array}$ & T value & MVP & MFC & $r$ & D \\
\hline Seed & 0.064 & 0.059 & 1.085 & 1.564 & 1 & 1.564 & 36.048 \\
\hline Fertilizer & 0.024 & 0.017 & 1.406 & 1.295 & 1 & 1.295 & 22.804 \\
\hline Manure & 0.010 & 0.011 & 0.925 & 0.706 & 1 & 0.706 & 41.705 \\
\hline Machinery and bullocks & $0.348^{* * *}$ & 0.090 & 3.846 & 1.632 & 1 & 1.632 & 38.718 \\
\hline Pesticide & $-0.027^{* * *}$ & 0.009 & -2.934 & -46.859 & 1 & -46.859 & 102.134 \\
\hline Labour & -0.155 & 0.098 & -1.579 & -0.463 & 1 & -0.463 & 315.805 \\
\hline Transportation & $0.222^{* * *}$ & 0.041 & 5.397 & 10.057 & 1 & 10.057 & 90.057 \\
\hline Constant & $7.276^{* * *}$ & 0.896 & 8.122 & & & & \\
\hline R Square & 0.428 & & & & & & \\
\hline Adjusted R Square & 0.385 & & & & & & \\
\hline Observations & 102.000 & & & & & & \\
\hline F value $(7,94)$ & $10.030^{* * *}$ & & & & & & \\
\hline Return to scale & 0.480 & & & & & & \\
\hline
\end{tabular}

Note: ${ }^{* * *}$ indicates significant at $1 \%$ level of significance. 
Estimation of efficiency ratios using Cobb-Douglas production function

Average estimated values of the regression coefficients, allocative efficiency ratio ' $r$ ' along with MVP and MFC and their related statistics of Cobb-Douglas production function are shown in the Table 5. Among the seven independent variables; seed, fertilizer, manure, machinery and bullocks, pesticides, labour and transportation, of production functions; machinery and bullocks, pesticides and transportation were significant at $1 \%$ level of significance. The regression coefficient for cost of machinery and bullocks were 0.348 , which indicates $100 \%$ increase in cost of machinery and bullock would lead to increase in gross return by $35 \%$. Similarly increase in cost of transportation by $100 \%$ would lead to increase in gross return by $22 \%$ (as regression coefficient is 0.222). And increase in cost of pesticides by $100 \%$ led to decrease in gross returns by $2.7 \%$ (as regression coefficient is -0.027$)$. The efficiency ratio less than $1-$ manure and labour; were overused in the study area, whereas, efficiency ratio greater than 1- seed, fertilizer, machinery and bullocks, pesticides and transportation; were underused resources. This findings agree with the findings of (Amaechina and Ebhoh, 2017) in which resource-use efficiency in rice production under small scale irrigation in Bunkure was studied. For the optimum allocation of resources, cost of manure and labour should be decreased by $41.70 \%$ and $315.80 \%$ respectively; and, cost of seed, fertilizer, machinery and bullocks, pesticide and transportation should be increased by $36.05 \%, 22.80 \%$, $38.72 \%, 102.13 \%$ and $90.06 \%$ respectively.

The overall $F$ value was 10.03 and it was statistically significant at $1 \%$ level. This indicates explanatory variables included in the model are important for the explanation of variation in production process. The adjusted $\mathrm{R}^{2}$ value of 0.385 indicates $38.5 \%$ variation in the production of rice was explained by the explanatory variables. The return to scale in the study area was observed as 0.480 which is decreasing return to scale.

\section{Conclusion}

From this study, it is concluded that benefit cost ratio of 1.59 was found in the case of plain area which was higher than hilly area. Similarly productivity of 5.2 ton/ha was found in plain area which was higher than national productivity of rice (3.39 ton/ha) and hilly area (3.33 ton/ha) in studied site. Production of rice is profitable in plain area whereas hilly area suffered loss although the cost of production is less in hilly area. The reason behind loss in hilly area was due to less production per household (only 0.8 ton) and less use of resources. Among the types of fertilizers, high amount of FYM use was found in hilly area and chemical fertilizer in plain area due to easy availability in respective places. This study identifies the inputs used in rice production were ineffectively utilized in which organic fertilizer and labour resource was overused and seed, fertilizer, machinery and bullocks, pesticides and transportation; were underused resources. The optimal allocation of these resources will increase profitability.

\section{ACKNOWLEDGEMENTS}

The authors would like to acknowledge Agriculture Knowledge Centre, Chitwan and Department of Agricultural Economics and Agribusiness Management, Agriculture and Forestry University, Chitwan for partial funding to accomplish this study.

Open Access: This is an open access article published under the terms and conditions of Creative Commons AttributionNonCommercial 4.0 International License which permits noncommercial use, distribution, and reproduction in any medium, provided the original author(s) if the sources are credited.

\section{REFERENCES}

Alimi.T. (2000). Resource use efficiency in food production Oyo stateof Nigeria. Journal of Agriculture and Environment, 1(1): 1-7.

Amaechina, C.E., Ebhoh, C.E. (2017). Resource use efficiency in rice production in the lower Anambra irrigation project, Nigeria. Journal of Development and Agricultural Economics, 9(8): 234-242.

CBS. (2017). Statistical Year Book, Central Bureo of Statistics, Kathmandu. Retrived from https://cbs.gov.np

CDD. (2015). Rice varietal mapping in Nepal: Implication for development and adoption. Kathmandu, Nepal: Crop Development Directorate, Department of Agriculture.

Deshar, B.D. (2013). An overview of agricuturedegradation in Nepal and its impact on economy and environment. Global Journal of Economy, Society and Development, 3: 1-20.

Dhakal, S.C., Regmi, P.P., Thapa, R.B., Sah, S.K. and Khatri-Chhetri, D.B. (2015). Resource use efficiency of mustard production in Chitwan district of Nepal. International Journal of Applied Sciences and Biotechnology, 3(4): 604608, https://doi.org/10.3126/ijasbt.v3i4.13525

Gujarati, D.N. (2009). Basic econometrics. Tata McGraw-Hill Education.

Hasnian, M.N. and Hossain, M.E.I.M. (2015). Technical efficiency of Boro rice production in Meherpur district of Bangladesh. American Journal of Agricultural Research, 3 (2): 31-37, http://dx.doi.org/ 10.11648/j.ajaf.20150302.14

Juliano, B.O. (1985) Criteria and Tests for Rice Grain Qualities. In: Rice Chemistry and Technology, 2nd Edition, American Association of Cereal Chemists, pp. 443-524

MOAD. (2016). Food and Nutritional Security in Nepal. Ministry of Agricultural Development, Department of Agriculture, Hariharbhawan, Lalitpur.

MOF. (2017). Economic Survey 2017. Ministry of Finance, Kathmandu, Nepal

Nargis, F. and Lee, S.H. (2013). Efficiency analysis of boro rice production in NorthCentral region of Bangladesh. The Journal of Animal and Plant Sciences, 23(2): 527-533.

NFS. (2010). National food security Atlas. Kathmandu: Ntional Development Research Institute.

Ogundele, O. and Okoruwa, V. (2006). Technical efficiency differentials in rice production technologies in Nigeria AERC Research Paper pp. 154.

Olukosi, J.O., Isitor, S.U. and Ode, M.O. (2006). Introduction to Agricultural Marketing and Prices: Principles and Applications, Living Book Series.

Osti, R., Zhou, D., Singh, D., Bhattarai and Chaudhary, H. (2016). An economic analysis of poultry egg production in Nepal. Pakistan Journal of Nutrition, 15: 715-724, http://dx.doi.org/10.3923/pjn.2016.715.724

Osti, R., Rizwan, M., Assefa, A.K., Zhou, D. and Bhattarai, D. (2017) Research Article Analysis of Resource-use Efficiency in Monsoon and Spring Rice Production in Nepal. Pakistan Journal of Nutrition, 6: 314-321, https://doi.org/10.3923/pjn.2017.314.321

Raosoft (2014). Sample size calculator. Retrieved September 9, 2017 from http://www.raosoft.com/samplesize.html.

Sapkota, S. and Sapkota, S. (2019). Benefit Cost Analysis of Different Rice Varieties in Kapilvastu Diatrict, Nepal. International Journal of Applied Science and Biotechnology, 7 (2): 222-226, https://doi.org/10.3126/ijasbt.v7i2.24210

Sapkota, M., Joshi, N.P., Kattel, R.R. and Bajracharya, M. (2018). Profitability and resource use efficiency of maize seed production in Palpa district of Nepal. SAARC Journal of Agriculture, 16(1): 157-168, https://doi.org/10.3329/sja.v16i1.37431 
Scheaffer, R. (1979). Elementary Survey Sampling. Massachusetts, USA, Duxbury Press Retrieved from https://trove.nla.gov.au/work/11710282

Shrestha, S. (2012). Status of agricultural mechanization in Nepal. United Nations Asian and Pacific Center for Agricultural Engineering and Machinery (UNAPCAEM).
Adhikari, R.K. (2011). Economics of organic rice production. Journal of Agriculture and Environment, 12: 97-103. https://doi.org/10.3126/aej.v12i0.7569

Perneger, T.V., Courvoisier, D.S., Hudelson, P.M. and Gayet-Ageron, A. (2015) Sample size for pre-tests of questionnaires. Quality of Life Research, 24(1): 147-151. 